\title{
The Moroccan Tax System and the Challenges of Economic Efficiency: Opportunities and Threats
}

\author{
Abdelkader Khanfor ${ }^{1}$, Youssef ELWAZANI ${ }^{2}$ \\ ${ }^{1}$ Ibn Zohr University, Faculty of Economics, Agadir, Morocco \\ ${ }^{2}$ Ibn Zohr University, National School of Business \& Management, PoB. 37 / S Qr Salam, Agadir, Morocco
}

\begin{abstract}
We cannot talk about economic efficiency in a country without mentioning its tax system. Indeed, economic development and the business climate are, among other things, based on the quality of existing tax system. The latter, by default, should offer the necessary guarantees of fair taxation, balanced and transparent taxation. Promoting tax compliance is a key issue of fiscal balance as well as for business ethics.
\end{abstract}

Keywords: Tax system, Morocco, Economic Efficiency, Fiscal, Organization.

\section{Introduction}

The relevance of fiscal policies should be assessed in the light of the large number of constraints and parameters that can help define an optimal taxation like tax incentives and the tax system complexity. Accordingly, the efficiency of a tax system cannot be judged only by its level of social equity neither by the contribution to tax revenues but mostly by its simplicity and the clarity of its rules.

Indeed, the assessment of the business climate in a given country, its economic competitiveness and its attractiveness of foreign direct investment, depends on the degree of transparency of its tax system. Hence, our interests in evaluating the effectiveness of the Moroccan tax system and its consistency with the aspirations of economic development.

We will try, therefore, through the evaluation of the Moroccan tax system, at first, to identify the strengths that would help boost economic activity, and secondly, to detect weaknesses and obstacles to economic development.

Our work complements previous research that showed that the complexity of the tax law and regulatory procedures that accompany it may partly explain the tax minimization, especially when it causes misunderstanding of the taxpayer and therefore produce a sense of iniquity.

However, if the taxpayer has today a greater legal protection than in the past, this protection remains patchy. Since in terms of fiscal control, the difference between the perception of reality and the reality itself often makes difficult an objective analysis.

Perret and Seville [1] state that the researcher can adopt three types of positioning: unique, multiple or appointed. In our case, we have adopted a posture of "moderate researcher" combining critical and realistic in the sense that we are an active participant in the construction of knowledge in our field of study. We stand, then, in what researchers call "positivism laid."
As part of this paper we have not sought to quantify the frequency (recurrences) of the facts, but rather to understand an organizational phenomenon. That is why we adopted a qualitative approach [2] [3] [4].

\section{Theoretical Background}

If the interest in the issue of reporting of tax authorities to the taxpayer was the first order given to policy makers and senior government officials, researchers from different specialties including sociologists ([5], [6], [7]) economists, managers and lawyers, were also interested about.

\subsection{Tax Efficiency versus social balance}

According Leroy [8], fiscal sociology questions the fundamental relationships between the tax, the state and society. Indeed, Lambert [9], in his sociological analysis explains the relationship of the taxpayer to the tax authorities (the State) is a very tense relationship, characterized by permanent sources of tensions and social conflicts. It reflects, he said, the image of political stability and social climate of a country. The author argues, moreover, that "the history of finance and taxation, reveals that building a strong and stable state generates the existence of a tax system and administrative organization of a very structured; by -ci against when they are attacked by the taxpaying citizens, state stability and its structure are being questioned."

According Leroy [8], sociology examines the fundamental relationships between the tax, the state and society. Indeed, Lambert [9], in his sociological analysis, explains the relationship of the taxpayer to the tax authorities (the State) is a very tense relationship, characterized by permanent sources of tensions and social conflicts. It reflects, he said, the image of political stability and social climate of a country. The author argues, moreover, that "the history of finance and taxation, reveals that building a strong and stable state generates a tax system and an administrative organization that are very structured ; however when they are attacked by the taxpaying citizens, the stability of the state and its structures are being challenged. " 


\section{International Journal of Science and Research (IJSR) \\ ISSN (Online): 2319-7064}

Index Copernicus Value (2013): 6.14 | Impact Factor (2014): 5.611

Therefore treating the relationship Tax Administration and taxpayer under a sociological approach, lead us to consider, as states Leroy [8], the tax as a social phenomenon and as a political problem. The author summarizes: "Fiscal sociology focuses on the Public Institutions intervention process around the tax. She questions the legitimacy of the State for the citizen and opens a reflection on social justice."

On another level, the relation administration-taxpayer translated into citizen-administration relationship, was the subject of several works in public management researchers. The sphere of public management is permeated by several issues including the qualitative and quantitative increase of requirements of citizens or users, budgetary constraints that weighing on States, that overloads the administrative system, and a democratic deficit sometimes denounced in light of the weakness of citizen participation. Bartoli [10] finds that the public organization is brought to innovate and bring political solutions, technical and / or managerial skills to solve equations with variables often contradictory.

Thus, to understand the role of the Tax Administration, we must appreciate it as a public administration that produces a public service. Chevallier [11] explains that the term "public service" evokes both, three types of meanings: institutional, legal and ideological, that interferes constantly and feed off each other. The notion of public service is therefore a complex concept, in which mix of indistinguishable manner, inseparable and indissoluble reality and myth, united by the cement of law.

Financial democracy, defined as the participation of citizens in choosing public finances has a positive impact on tax compliance. Recent empirical works [12] establish a positive link between the power to decide and tax compliance. The tax involves, in fact, the legitimacy of public institutions [5].

\subsection{Taxpayer Tax-Administration Relationship}

We find in the study of the behavior of the taxpayer against the tax is based on the wide model of rationality in social sciences, synthesized by the sociologist Raymond Boudon. The logic of the taxpayer is attributable to economic interest, political legitimacy, especially by the fact that tax knowledge of the taxpayer is limited. The economic interest (utilitarian) to avoid tax is not the only factor to consider when studying avoidance. We should take into account the values of the individual, and the limitations of its practical knowledge.

Leroy [8], for its part, denies any correlation between the tax compliance and degree of wealth from taxpayers. By cons, Etzioni [13], quoted by Leroy [8], concludes that for USA, tax evasion is linked to the sense of injustice in the tax system in public opinion (for 1960 -1980), while the rates of the taxs remained stable. In addition, the survey conducted by Dubergé [14] in France, shows that $60 \%$ of people take more into account the "psychological costs", including the complexity of the tax and the tax return, and not the amount that they must pay.

Some authors [15] go as far as declaring that the deterrent effect associated with the feeling of guilt disappears with the complexity of the tax law which makes any accurate statement almost inaccessible. This favors, according to Thurman and Riggs [15], the development of fraudulent behavior.

Also Beltrame [16] wanted to clarify that: "In all of these works emerges the idea that it is important for the proper application of the tax that is equitably distributed, easy to apply and offers all guarantees of justice to the taxpayer, it is even more essential to disarm the prejudices and aversion towards the taxpayer's tax liability and improve its relations with the Administration to ensure that his fiscal sacrifice appear as it really is, an honorable contribution to public office."

\section{Moroccan Tax System: The Gaps}

In Moroccan texts, it is stated that the Tax Department has the following functions:

- Sit state taxes and recover;

- Ensure proper enforcement;

- Manage, on behalf of local governments, some local taxes.

According to the laws that define the role and prerogatives of the General Tax Department, one of these is considered an administrative institution that performs a public service mission in the general interest. Therefore its main mission is to fairly determine the tax payable by the taxpayer to supply the state budget. To do this, it's to for the TaxAdministration to justify its action and to explain the meaning of its approach. This pedagogical explanation sake generates specific terms of the taxpayer's socialization.

The Tax Administration is faced with two essential challenges: how to explain complex tax system and criticized from all sides? How to justify his action generally considered repressive way?

The taxpayer does not trust his administration and would prefer to consult a tax advisor or accountant to complete his statement rather than to go to the tax office to ask a competent agent for a free help in this task. This is not only related to a misunderstanding of the operation of the service, says Lambert [9], it reflects a mindset steeped in mistrust and apprehension.

The action of the Tax Administration shall, as Lambert [9] argues, bring to this level of information and socialization of the citizen taxpayer.

\subsection{Animosity towards the tax system}

Hincker [17] postulated that the rejection of the tax authorities is not new and that history is full of lessons in this regard. This rejection may, according to the author, be generator revolts succeed, little by little to a questioning of the legitimacy of political power and administrative institutions as a whole.

\section{Volume 5 Issue 2 February 2016}




\section{International Journal of Science and Research (IJSR) \\ ISSN (Online): 2319-7064}

Index Copernicus Value (2013): 6.14 | Impact Factor (2014): 5.611

Animosity towards the Tax Administration is evident in the opinions and behavior of citizens. It is, indeed, considered by Lambert [9], as an obstacle to the freedom of the taxpayer or citizen-entrepreneur, knowing she produced standards and laws, it requires, checks and sanctions where appropriate taxpayers nonscheduled.

Lambert [9] found that the Tax Administration is subject to the same criticisms usually leveled against the government: slow, cumbersome, formalism. This criticism of inefficiency relates generally all the work of the administration and especially its main mission, the tax audit.

\subsection{Transparency: origin of confidence}

According to Mohamed MOINDZE, good governance of public finances is essential for the success of these public actions. It is evaluated in terms of four main areas: accountability, participation, predictability and transparency. Transparency of public finances is defined as "clear public information on the structure and functions of government, the aims of fiscal policy, public sector accounts and fiscal projections." Thus according to Dervin [18], the "right" information sufficient, rigorous and accessible, is a prerequisite for the "good" democracy.

\section{Moroccan Tax System: The Advantages}

The administrative democracy has been translated into a lot, by the introduction of the charter of the taxpayer in 2011. Since then, the evolution in the relationship with the administration of the taxpayer has become very important, made by anchoring rights and guarantees of the two often antagonistic parties.

This trend continued twofold: at first, it promotes and facilitates the legal information of taxpayers (Facilitating access to law and to administrative documents).

Secondly, it recognizes the rights and guarantees to citizens. Those guarantees are mentioned:

- Need for clarity, intelligibility and accuracy of tax statements,

- Motivation of the administrative decision (reasons, adversarial procedure, express or implied decision, legal actions,...).

- Rules of form and procedure. Spontaneous recognition of defects in form or substance of the proceedings by the cancellation of adjustments.

In general, the concept of transparency can be measured by the level of voluntary disclosure and steady increasing amount of recent, comprehensive, relevant, rigorous and highly reliable on government activities for the benefit of the population. Also the ease of access to documents whose population needs to assess their actions and to exercise its voice in the decision-making process [19].

In this sense Curtin and Meijer [20], stressed that "transparency can strengthen the will of the people to accept the institutional structures in many ways ..."

\subsection{Tax Compliance}

Constitutional, tax compliance, now defined by Article 39 as an obligation and prerequisite for citizenship "All support in proportion to their contributory power, public office that only the law can, in the manner provided by this Constitution, create and distribute. "It can be defined as "the voluntary fulfillment of their tax return obligations and payment of taxes by the taxpayer."

In this sense the former Minister Nizar Baraka in mroccan government explained that "It is now necessary to move the observation that makes the tax burden or a punishment to the logic of a fundamental principle of citizenship."

In seeking explanations of the tax from taxpayers incivility appear the causes of conflict that take the tax system -even him and political choices.

In our observation we identified six explanations for the fiscal incivility: the feeling of injustice, inequity, complexity and illegibility of tax law, the lack of trust and communication between the Tax Administration and taxpayer.

- The lack of readability of tax laws: The lack of readability and clarity of the clauses mentioned in FIG tax system by taxpayers. It develops a strong sense of injustice, expressed by traders, even more intense among those who competed were unfair manner by persons engaged in informal activities. Readability and simplicity of the tax system and appear as major parameters, both because they underlie of injustice among taxpayers and affect their risk management and costs. Generally, opacity and complexity are an encouragement to the development of avoidance strategies and those of fraud.

- A sense of unfairness: The levy of the tax is judged not only unreadable, but still too complex. This complexity leads to widely denounced iniquity. Thus, it is clear that without full coverage of the tax fabric, it produces scammers (informal activity), or offers to big companies the means to engage with impunity in large scale of fraud, at least to avoid a substantial part of their revenues subject to tax obligations. Clearly, impunity at this scale can lead to a sense of injustice among the ordinary taxpayer is little incentive to tax compliance. Conversely, a real policy to fight against this fraud, which would not only conduct the identified taxpayers, but also to all persons exercising a taxable activity to applicable law eyes, could certainly be conducive to tax compliance.

- A crisis of confidence: more taxpayers doubt the sincerity of information on tax revenues and the distribution of the burden on all the Moroccan tax tissue (the most common is the one slogan: Only the poor pay taxes).

Addressing the tax act of incivility suppose diversified, balanced, coherent and simultaneous on all its causes. Examples include:

- Reduce gains tax fraud and increase the risk of the incivility tax: the tax can be reduced by reducing incivility earnings uncivil practices;

- Increase the opportunity costs of the tax incivility and 


\section{International Journal of Science and Research (IJSR) \\ ISSN (Online): 2319-7064}

Index Copernicus Value (2013): 6.14 | Impact Factor (2014): 5.611

limit those tax compliance: simplify tax regularity and increase the costs of deviance standards;

- Preventing antisocial practices to fiscal charges;

- Fight against the phenomena of snobbery and imitation fraudsters: Correct these two behaviors requires strong political impetus, with communication campaigns declined to all public (even in schools) and diverse media;

- Building trust: The rights and obligations of taxpayers stipulated by the charter of the taxpayer (2011), in terms of fiscal control, found under the heading of "fundamental principles", the presumption of good faith of the taxpayer. This said, all statements and accounting documents filed or submitted to the tax authorities are presumed accurate and regular. In this sense, Abdelatif Zaghnoun, General Director of Taxation confirmed that "Legal certainty is based on certain principles such as the presumption of good faith, recognition of the control of the administration of law, guaranteed control in a legal procedure, the right to defense in adversarial proceedings and the right to be assisted by counsel of choice. The Moroccan tax system is a declarative system based on spontaneous reporting and payment of the corresponding rights as well as confidence." Despite the confidence building that is one of the strategic guidelines of the General Directorate of Taxation, according to Omar Raissouni, it remains one of concepts ignored in an instrumental context that does not allow the reduction of complexity and uncertainty of administrative action.

The current report shows that fiscal control in its technical and procedural dimension requires the introduction of concepts like trust which will probably lead to the enrichment of the understanding of the tax audit.

The link between the two opposing concepts: confidence (perceived as positive) and control (called negative) may seem paradoxical, while several researchers expressed a strong junction of the two concepts, as two sides of the same coin, essential, as well as the other, the reduction of the uncertainty and to decrease the complexity of the organizational situations.

And although tax revenues have accounted for $72 \%$ of total revenue of the general government budget in 2011, the DGI has been heavily criticized both by the Court of Auditors and the Economic and Social Council.

Following this, the Ministry of Economy and Finance organized the National Conference on Taxation, 29 and 30 April 2013. The aim was to open to the general public, to promote the exchange of points view and mainly come out with practical solutions that can provide the Moroccan tax system for a new pulse.

Indeed, basically, the major concern is that of being in line with the political, economic and social of our country.

These national meetings, among other recommendations, formulated proposals mainly aim at strengthening the means of action of the administration on fiscal control, and improved guarantees of the taxpayer, with the aim of rebalancing relationship between the Tax Administration and administered.

Looking ahead to build, with the taxpayer, a relationship of trust and partnership, the General Tax Directorate in Morocco, like the European countries, introduced the charter of the taxpayer under section 7 of the Finance Act No. 43-10, for the 2011 budget year.

This charter constitutes an excelling summary of Book II of the CGI "Tax procedures" which is considered as a very good documentation support, which should in theory be the legal reference establishing a reciprocal manner, the relationship between the tax authorities and users during the tax audit.

In all fairness, it must be recognized that this document, of general application, applies only to the taxpayer's accounting verification phase. In addition, all rendered, summaries by the Economic and Social Council and the National Conference on Taxation in Morocco, highlights the blatant lack of legal guarantees of the taxpayer in those prior to the inspection on the premises during the internal control and during the investigation and programming missions.

According to other experts consulted during our observation phase, the recipient of that Charter did not even feel concerné1par its content, since the style of the wording of the latter remains impersonal; in the sense that it does not directly involve the taxpayer.

\section{Conclusion}

In conclusion, the results of our analysis, we found that:

- At the first hypothesis, the collected answers taught us that not only the taxpayers have difficulty assimilating the tax standard, but the means deployed by the Tax Administration to inform the taxpayer also remain limited.

- The response of those solicited about our question regarding our second hypothesis showed us that strengthening the dissemination of information and the extension of tax practices, could help build confidence taxpayer by securing the necessary arguments to understand and defend themselves, to accept the tax audit as a legitimate right of the Tax Administration.

- The guarantees offered by the Moroccan charter raised a lot of criticism from taxpayers and advice. We believe it is time for the Tax Administration to review the style of this charter, while ensuring simplifying and explaining the guarantees to which it refers.

- Taxpayers complain the quality of services dedicated to the control and the provisions governing the tax control, they then proposed some points for reflection as they consider appropriate, for a better climate control.

Thus, almost all taxpayers, suffering from fierce competition from tax delinquents. According to the sources, the tax fairness is questioned and the Tax Administration must ensure apprehend these actors to ensure a better distribution 


\section{International Journal of Science and Research (IJSR) \\ ISSN (Online): 2319-7064}

Index Copernicus Value (2013): 6.14 | Impact Factor (2014): 5.611

of the tax burden.

Organizational cultures cannot be decreed but are built, through time, so patient and slow. We cannot, therefore, establish new values overnight, especially when these values guide and truly underlie individual and collective behavior.

In addition, the values related to the emergence of conflict of "market" components in a world broadly defined by "civil" references are potentially destructive and create a durable confusion. This is reinforced by the fact that the cultural dimension has often been the "poor relation" of the ongoing reform process, oriented primarily on "hard" factors. A key challenge here is waiting public organizations to define a new public service culture, valuing specific assets to public service (citizenship, transparency, fairness and social responsibility in particular).

\section{References}

[1] PERRET, V., \& SEVILlE, M., (2003), Méthodes de recherche en management, chapoter Fondements épistémologiques de la recherche, pp. 13-33.

[2] MUCCHIELLI, A., (1994), Les méthodes qualitatives, éd, Paris : PUF.

[3] WACHEUX, F., (1996), Méthodes qualitatives et recherche en gestion, éd, Economica.

[4] GIORDANO, Y, (2003), Conduire un projet de recherche, une perspective qualitative », éd, EMS.

[5] LEROY, M. (2002), Sociologie de l'impôt. Presses universitaires de France.

[6] LEROY, M. (2007), Découvrir la sociologie fiscale, Regards croisés sur l'économie 1/ 2007 (n 1), p. 94 100.

[7] REYNAUD, P-L., (1947), La psychologie du contribuable devant l'impôt, Revue de Science et de Législation Financière, pp. 394 -411.

[8] LEROY, M. (2009), La sociologie fiscale. Socio -logos. Revue de l'association française de sociologie.

[9] LAMBERT, T, (1985), Le contribuable face à l'Administration Fiscale, In Psychologie et Science Administrative, Centre Universitaire de Recherches Administratives et Politiques de Picardie, pp : 102 121.

[10] BARTOLI, A. (2009), Management dans les organisations publiques, 3ème éd, Paris Dunod, p. 424.

[11] CHEVALLIER, J., (1988), Le mythe de la transparence administrative, in Information et transparence administratives, CURRAP, PUF, p. 240.

[12] ALM, J., MCCLELLAND, G. H., \& SCHULZE, W. D. (1992), Why do people pay taxes? Journal of Public Economics, 48(1), pp. 21 -38.

[13] ETZIONI, A. (1986), The case for a multiple -utility conception. Economics and Philosophy, 159 -184.

[14] DUBERGÉ, J. (1990), Les français face à l'impôt: essai de psychologies fiscales. Librairie Générale de Droit et de Jurisprudence.

[15] THURMAN, Q. C., JOHN, C. S., \& RIGGS, L, (1984), Neutralization and tax evasion: How effective would a moral appeal be in improving compliance to tax laws? Law \& Policy, 6(3), pp. 309 -327.
[16] BELTRAME, P., \& MEHL, L. (1997), Techniques, politiques et institutions fiscales comparées. Presses universitaires de France.

[17] HINCKER, F. (1971), Les Français devant l'impôt sous l'Ancien Régime, Flammarion, coll. Questions d'histoire, p 182.

[18] Dervin, B. (1994). Information $\leftrightarrow$ democracy: An examination of underlying assumptions. Journal of the American Society for Information Science, 45(6), 369385.

[19] Florini, A. (2007). Introduction: The battle over transparency. The right to know. transparency for an open world, 1-16.

[20] Curtin, D., \& Meijer, A. (2006). Does Transparency Strenghten Legitimacy? A Critical Analysis of European Union Policy Documents. Information polity.

\section{Author Profile}

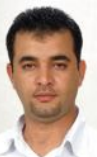

Abdelkader Khanfor is Associate Professor at Ibn Zohr University, he holds a PhD in Economics and is a specialist in matters of taxation. Khanfor is also a Divisional Inspector at the Regional Directorate of Taxes SMD.

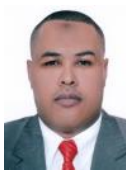

Youssef El Wazani is Full Professor at Ibn Zohr University, National School of Business and Management. He is the Director of the Research Group in Management and Performance of Public, Private Organizations and Social Economy. 